\title{
DAMPAK KONFLIK KELUARGA-PEKERJAAN DAN MOTIVASI INTRINSIK TERHADAP KINERJA KERJA
}

\author{
Silky Pentanesia Mantik \\ Sunjoyo \\ Universitas Kristen Maranatha \\ Email: silkymantik@gmail.com; sunjoyogrd@yahoo.com
}

Submitted: Oct 18, 2017; Reviewed: Oct 20, 2017; Accepted: Sept 3, 2018

\begin{abstract}
This study aimed to determine the effect of work-family conflict and intrinsic motivation on job performance. The data used in this research is primary data which is taken by disseminating the questionnaire. Subjects in this research are the employees in 3 companies which are, PT X and BPR $X$, located in Bandung and Bank X, located in Semarang. A total 206 usable questionnaires were collected. Samples are selected by using probability sampling and convenience sampling method. The analytical method used in this research is multiple linear regressions. The result showed that only one hypotheses was supported from two hypotheses. The implication of this study is discussed and the suggested research is advanced during the process.
\end{abstract}

Keywords: Work-Family Conflict, Intrinsic Motivation, Job Performance

\section{PENDAHULUAN}

Suatu keberhasilan yang ingin dicapai oleh perusahaan sangat dipengaruhi oleh kinerja kerja karyawannya, menurut Marwansyah (seperti yang dikutip dalam Sanjaya \& Indrawati, 2014). Douglas (seperti yang dikutip dalam Afriansyah, 2014) menjelaskan bahwa perusahaan membutuhkan karyawan yang mempunyai kinerja kerja (job performance) yang tinggi, sehingga perusahaan akan mampu bersaing secara berkelanjutan dan terus mengalami perkembangan ke arah yang lebih baik (Suparta, 2013).

Kinerja kerja seorang karyawan dipengaruhi oleh banyak faktor. Wirawan (seperti yang dikutip dalam Hakim, 2016) menyatakan kinerja kerja dipengaruhi oleh faktor intrinsik yaitu personal/individual dan faktor ekstrinsik yaitu kepemimpinan, sistem, tim, situasional, dan konflik. Martoyo (seperti yang dikutip dalam Suparta, 2013) mengungkapkan bahwa faktor yang berpengaruh terhadap kinerja antara lain motivasi, kepuasan kerja, kepemimpinan dan perilaku lainnya. Dalam penelitian ini peneliti tertarik untuk membahas konflik terutama konflik keluarga-pekerjaan (work-family conflict) dan motivasi terutama motivasi intrinsik sebagai faktor yang memengaruhi kinerja kerja.

Keberadaan konflik dalam suatu perusahaan tidak dapat dihindarkan, dengan kata lain konflik selalu hadir (Istomo, 2013). Salah satu konflik di sebuah organisasi atau perusahaan adalah konflik keluarga-pekerjaan. Burke dan ElKot (seperti yang dikutip dalam Roboth, 2015) serta Grandey, Cordeino dan Crouter (seperti yang dikutip dalam Roboth) mengemukakan konflik keluarga-pekerjaan dianggap telah menjadi masalah yang penting dalam dunia bisnis saat ini. Carlson, Kacmar dan Williams (seperti yang dikutip dalam Mulyandini, Lelly, \& Tobing, 2015) menyatakan konflik keluargapekerjaan terjadi akibat adanya konflik antar peran ketika pemenuhan salah satu peran bisa menekan peranan yang lain, baik itu perannya di kehidupan pekerjaan atau keluarga. Sulitnya menyeimbangkan urusan pekerjaan dan keluarga dapat menimbulkan konflik keluarga-pekerjaan. Saltzein, Ting dan Saltzein (seperti yang dikutip dalam Pragita, 2009) menyatakan konflik pekerjaan dan kehidupan sehari-hari dapat memengaruhi kinerja kerja.

Faktor berikutnya yang dapat memengaruhi kinerja kerja adalah motivasi 
intrinsik. Deci dan Ryan (seperti yang dikutip dalam Harshanty, 2011) menyatakan orang yang termotivasi secara intrinsik akan berkomitmen terhadap suatu tugas dibanding mereka yang termotivasi secara ekstrinsik. Wilson (seperti yang dikutip dalam Suparta, 2013) menyatakan bahwa motivasi intrinsik sangat memengaruhi seseorang dalam mengembangkan kompetensinya yang berujung pada peningkatan kinerjanya. Melalui motivasi intrinsik membuat karyawan sadar akan tanggung jawab dan pekerjaannya yang lebih baik dan terdorong untuk semangat menyelesaikan dengan baik pekerjaannya (Prahiawan \& Simbolon, 2014).

Penelitian terdahulu mengenai konflik keluarga-pekerjaan dilakukan oleh Susanto dan Mogi (2016) menyatakan terdapat pengaruh negatif konflik keluarga-pekerjaan terhadap kinerja kerja. Hasil studi tersbut bertentangan dengan penelitian yang dilakukan oleh Christine, Oktorina, dan Mula (2010) serta Widyaningrum, Pongtuluran, dan Tricahyadinata (2013) yang menyatakan terdapat pengaruh positif konflik keluarga-pekerjaan terhadap kinerja kerja. Studi mengenai motivasi intrinsik terhadap kinerja kerja dilakukan oleh Suparta (2013), Akbar (2012), serta Lukito, Haryono, dan Warso (2013) yang menyatakan bahwa motivasi intrinsik berpengaruh positif terhadap kinerja kerja.

Peneliti tertarik untuk melakukan pengembangan dari beberapa studi terdahulu (Akbar, 2012; Christine, Oktorina, \& Mula, 2010; Lukito, Haryono, \& Warso, 2013; Susanto \& Mogi, 2016; Widyaningrum, Pongtuluran, \& Tricahyadinata, 2013) seperti yang telah dijelaskan sebelumnya. Peneliti ingin mendapatkan jawaban empiris mengenai bagaimana dampak konflik keluarga-pekerjaan dan motivasi intrinsik terhadap kinerja kerja.

\section{KAJIAN PUSTAKA \\ Konflik Keluarga-pekerjaan}

Greenhaus dan Beutell (1985) mendefinisikan konflik keluarga-pekerjaan (work-family conflict) sebagai bentuk konflik peran dimana tuntutan peran pekerjaan dan keluarga secara mutual tidak dapat disejajarkan dalam beberapa hal. Frone, Rusell, dan Cooper (seperti yang dikutip dalam Siregar, 2011) menyatakan work-family conflict sebagai konflik peran yang terjadi pada karyawan, dimana di satu sisi ia harus melakukan pekerjaan di kantor dan di sisi lain harus memperhatikan keluarga secara utuh, sehingga sulit membedakan antara pekerjaan mengganggu keluarga dan keluarga mengganggu pekerjaan.
Carlson, Kacmar, dan Williams (seperti yang dikutip dalam Mulyandini, Lelly, \& Tobing, 2014) menyatakan work-family conflict terjadi akibat adanya konflik antar peran ketika pemenuhan salah satu peran bisa menekan peranan yang lain, baik itu perannya di kehidupan pekerjaan atau keluarga.

\section{Motivasi Intrinsik}

Istilah motivasi (motivation) berasal dari bahasa latin yaitu movere, yang berarti "menggerakkan" (to move). Teori yang dikembangkannya oleh Herzberg dikenal dengan "Model Dua Faktor" dari motivasi, yaitu faktor motivasional dan faktor hygiene atau "pemeliharaan". Menurut teori ini yang dimaksud faktor motivasional adalah hal-hal yang mendorong berprestasi yang sifatnya intrinsik, yang berarti bersumber dalam diri seseorang, sedangkan yang dimaksud dengan faktor hygiene atau pemeliharaan adalah faktorfaktor yang sifatnya ekstrinsik yang berarti bersumber dari luar diri yang turut menentukan perilaku seseorang dalam kehidupan seseorang. Herzberg (seperti yang dikutip dalam Arniadi, 2015) membagi teori motivasi ke dalam dua bentuk:

\section{Motivasi intrinsik}

Motivator (intrinsik) adalah motivasi yang mendorong seseorang untuk berprestasi yang bersumber dalam diri individu tersebut, merupakan faktor penting yang mampu memberikan dorongan atau motivasi kerja dalam diri karyawan yang berdampak pada hasil pekerjaanya.

\section{Motivasi ekstrinsik}

Motivasi ekstrinsik adalah motivasi yang bersumber dari luar diri yang turut menentukan perilaku seseorang dalam kehidupan seseorang. Faktor hygiene mempertahankan tingkat motivasi kerja karyawan jika faktor tersebut diberikan secara tepat Jika factor tersebut diberikan secara tidak tepat akan berdampak pada menurunya semangat dan hasil kerja karyawan.

\section{Kinerja Kerja}

Moeheriono (seperti yang dikutip dalam Wulandari, 2013) mengemukakan kinerja atau performance merupakan gambaran mengenai tingkat pencapaian pelaksanaan suatu program kegiatan atau kebijakan dalam mewujudkan sasaran, tujuan, visi, dan misi organisasi yang dituangkan melalui perencaan strategis suatu 
organisasi. Mathis (seperti yang dikutip dalam Muizzudin, 2014) menyatakan kinerja kerja adalah sesuatu yang memengaruhi seberapa banyak karyawan memberi kontribusi kepada organisasi yang antara lain temasuk kuantitas output, kualitas output, jangka waktu output, kehadiran ditempat kerja dan sikap kooperatif. Kinerja yang baik adalah kinerja yang optimal, sesuai dengan standar dan kriteria yang ditetapkan dalam mendukung tercapainya tujuan perusahaan (Palokoto, 2014).

\section{Hubungan Antarkonstruk Penelitian \\ Hubungan antara Konflik Keluarga- pekerjaan dan Kinerja Kerja}

Konflik keluarga-pekerjaan berpengaruh negatif terhadap kinerja kerja. Hal ini dibuktikan berdasarkan beberapa hasil studi yang dilakukan oleh Indriyani (2007), Kusumawardhani, Suprayitno, dan Utami (2014), serta Tjokro dan Asthenu (2015). Karyawan yang mengalami tingkat konflik keluarga-pekerjaan yang tinggi melaporkan menurunnya kinerja kerja karena merasa lebih dikuasai oleh masalah dalam keluarganya yang mengakibatkan karyawan tidak bisa memenuhi tanggung jawab pekerjaannya secara maksimal, karena mengurangi kualitas pekerjaannya (Sulistiowati, 2012). Berdasarkan beberapa hasil penelitian tersebut, maka hipotesis yang dirumuskan adalah sebagai berikut:

Hipotesis 1: Konflik keluarga-pekerjaan berpengaruh negatif terhadap kinerja kerja.

\section{Hubungan antara Motivasi Intrinsik dan Kinerja Kerja}

Motivasi sangat memengaruhi keberhasilan suatu organisasi, terutama dalam usaha untuk meningkatkan kinerja kerja (Linawati, 2014). Penelitian yang dilakukan oleh Maulana, Hamid, dan Mayoan (2015) menunjukan motivasi instrinsik bertanda positif sebesar 21 persen, yang berarti perubahan motivasi instrinsik searah dengan nilai kinerja. Hasil penelitian tersebut mengkonfirmasi beberapa hasil studi yang dilakukan oleh Astrini (2012), Hidayanti (2016), Karatepe dan Tekinkus (2006), Mudayana (2010), dan Sleimi dan Davut (2015) yang menyatakan terdapat pengaruh positif motivasi intrinsik terhadap kinerja kerja. Berdasarkan beberapa hasil studi tersebut, hipotesis yang dirumuskan adalah sebagai berikut:

Hipotesis 2: Motivasi intrinsik berpengaruh positif terhadap kinerja kerja.
Berdasarkan 2 (dua) hipotesis yang telah dirumuskan, maka model penelitian studi ini adalah sebagai berikut:

Gambar 1. Model Penelitian yang Dihipotesiskan

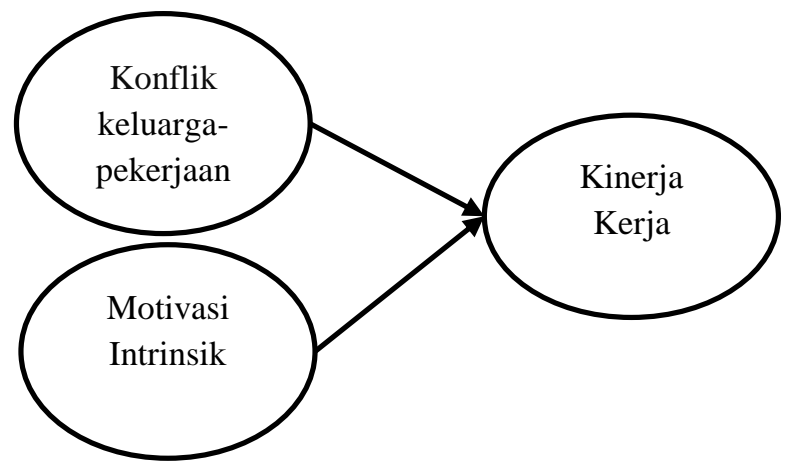

Sumber: Altzein, Ting dan Saltzein (seperti yang dikutip dalam Pragita, 2009) dan Wilson (seperti yang dikjutip dalam Suparta, 2013)

\section{METODE PENELITIAN \\ Jenis Penelitian}

Penelitian ini betujuan untuk menguji dan menganalisis ada atau tidaknya pengaruh konflik keluarga-pekerjaan dan motivasi intrinsik terhadap kinerja kerja. Berdasarkan tujuan penelitian tersebut maka jenis penelitian ini adalah causal explanatory. Causal adalah suatu variabel memengaruhi variabel yang lain (Cooper \& Schindler, 2011). Explanatory research adalah penelitian yang bertujuan untuk menjelaskan hubungan antar variabel dan fenomena penelitian (Cooper \& Schindler, 2011).

\section{Populasi dan Sampel Penelitian}

Populasi dalam penelitian ini adalah 3 perusahaan yang terdiri dari PT X, BPR X dan Bank X. Penelitian ini menggunakan nonprobability sampling. Non-probability sampling adalah teknik pengambilan sampel yang tidak memberi peluang/kesempatan yang sama bagi setiap unsur anggota populasi untuk dipilih menjadi anggota sampel (Sugiyono, 2012). Selain itu dilakukan juga pengambilan sampel dengan teknik convenience sampling atau biasa disebut dengan accidental sampling. Sugiyono (seperti yang dikutip dalam Hamidi, 2015) menyatakan accidental sampling adalah mengambil responden sebagai sampel berdasarkan kebetulan, yaitu siapa saja yang kebetulan bertemu dengan peneliti dapat digunakan sebagai sampel bila orang yang 
kebetulan ditemui cocok sebagai sumber data dengan kriteria utamanya.

Teknik pengumpulan data menggunakan metoda survei dengan alat bantu kuesioner. Sampel dalam penelitian ini berjumlah 206 responden. Penentuan jumlah sampel riset multivariat (termasuk analisis regresi majemuk) didasarkan pada pernyataan yang dikemukakan oleh Sekaran dan Bougie (2009) bahwa ukuran sampel yang baik dapat ditentukan dengan cara, jumlah pernyataan dalam kuesioner dikali sepuluh atau lebih. Dalam penelitian ini, perhitungan minimal samplenya adalah 18 butir pernyataan dikali 10 menjadi 180 sampel.

\section{Definisi Operasional Variabel}

Kuesioner dalam penelitian ini terdiri atas 18 butir pernyataan (terlampir pada halaman belakang). Konflik keluarga-pekerjaan. Konstruk ini diukur dengan 7 butir pernyataan. Kuisioner yang digunakan diadopsi dari Burke et al. (seperti yang dikutip dalam Karatepe \& Tekinkus, 2006). Skala pengukuran menggunakan skala Likert dengan rentang 1 (sangat lemah), 2 (lemah), 3 (netral), 4 (kuat), dan 5 (sangat kuat). Butir-butir tersebut telah digunakan Karatepe dan Tekinkus (2006) dengan koefisien Cronbach's alpha sebesar 0,87.

Motivasi intrinsik. Konstruk ini diukur dengan 4 butir pernyataan. Kuesioner yang digunakan diadopsi dari Low, Cravens, Grant, \& Moncriev (2001). Skala pengukuran menggunakan skala Likert dengan 1 (sangat tidak setuju), 2 (tidak setuju), 3 (netral), 4 (setuju), dan 5 (sangat setuju). Butir-butir tersebut telah digunakan Karatepe dan Tekinkus (2006) dengan koefisien Cronbach's alpha sebesar 0,82.

Kinerja kerja. Konstruk ini diukur dengan 7 butir pernyataan. Kuesioner yang digunakan diadopsi dari Singh, Verbeke, dan Rhoads (seperti yang dikutip dalam Babin \& Boles, 1998). Skala pengukuran menggunakan skala Likert dengan 1 (sangat tidak setuju), 2 (tidak setuju), 3 (netral), 4 (setuju), dan 5 (sangat setuju). Butir-butir tersebut telah digunakan Babin dan Boles (1998) dengan koefisien Cronbach's alpha sebesar 0,89.

Variabel kontrol. Variabel kontrol dalam studi ini terdiri atas lima yang dianggap memiliki hubungan erat dengan variabel utama studi ini yang terdiri atas: jenis kelamin $(0=$ laki-laki; $1=$ perempuan), usia $(1=$ dibawah atau sama dengan 25 tahun; $2=26$ tahun hingga 30 tahun; $3=31$ tahun hingga 35 tahun; $4=36$ tahun hingga 40 tahun; $5=$ diatas 40 tahun), pendidikan ( $1=\mathrm{SD}$;
$2=\mathrm{SMP} ; 3=\mathrm{SMA} 4=\mathrm{S} 1 ; 5=\mathrm{S} 2)$, status $(0=$ belum menikah/tidak menikah; 1 = menikah), jumlah anak $(1=$ belum/tidak memiliki anak; $2=$ 1 anak; $3=2$ anak; $4=3$ anak; $5=4$ anak; $6=$ $>4$ anak), dan masa jabatan di perusahaan $(1=$ $<1$ tahun; $2=1-5$ tahun; $3=6-10$ tahun; $4=11$ 15 tahun; $5=16-20$ tahun; $6=>20$ tahun) (Karatepe \& Tekinkus, 2006).

\section{HASIL ANALISIS DATA}

Subjek penelitian ini adalah karyawan di 3 (tiga) perusahaan, terdiri atas PT X dan BPR X, yang terletak di Kota Bandung serta Bank X, yang terletak di Kota Semarang. Kuesioner disebar melalui 2 (dua) bentuk yaitu dalam lembaran kertas dan dalam bentuk online. Jumlah kuesioner yang disebar dalam bentuk lembaran adalah sebanyak 220 dan yang kembali adalah sebanyak 181. Namun sebanyak 4 (empat) data tidak dapat diikutsertakan dalam pengolahan data karena ketidaklengkapan pengisian data tersebut. Melalui kuesioner online, terkumpul sebanyak 29 (dua puluh sembilan) data. Jumlah data yang dapat digunakan adalah sebanyak 206. Karakteristik responden dalam penelitian ini terbagi menjadi jenis kelamin, usia, pendidikan, status pernikahan, jumlah anak, dan lama bekerja. Data mengenai karakteristik responden dapat dilihat pada Tabel 1.

Tabel 1. Karakteristik Responden

\begin{tabular}{|c|c|c|c|}
\hline Variabel & Karakteristik & Jumlah & Presentase (\%) \\
\hline \multirow{2}{*}{ Jenis Kelamin } & Laki-laki & 174 & 84,5 \\
\hline & Perempuan & 32 & 15,5 \\
\hline \multirow{5}{*}{ Usia } & $\leq 25$ tahun atau sama dengan 25 tahun & 45 & 21,8 \\
\hline & 26 tahun hingga 30 tahun & 58 & 28,2 \\
\hline & 31 tahun hingga 35 tahun & 38 & 18,4 \\
\hline & 36 tahun hingga 40 tahun & 44 & 21,4 \\
\hline & $>40$ tahun & 21 & 10,2 \\
\hline \multirow{5}{*}{ Pendidikan } & SMP & 4 & 1,9 \\
\hline & SMA & 102 & 49,5 \\
\hline & Diploma $1,2,3$ & 23 & 11,2 \\
\hline & S1 & 73 & 35,4 \\
\hline & S2 & 4 & 1,9 \\
\hline \multirow{2}{*}{ Status } & Tidak belum menikah & 69 & 33,5 \\
\hline & Menikah & 173 & 66.5 \\
\hline \multirow{6}{*}{ Jumlah Anak } & Tidakbelum memiliki anak & 93 & 45,1 \\
\hline & 1 anak & 47 & 22,8 \\
\hline & 2 anak & 51 & 24,8 \\
\hline & 3 anak & 12 & 5,8 \\
\hline & 4 anak & 3 & 1,5 \\
\hline & $>4$ anak & - & - \\
\hline \multirow{6}{*}{ Lama Bekerja } & $<1$ tahun & 31 & 15 \\
\hline & $1-5$ tahun & 113 & 54,9 \\
\hline & 6-10 tahun & 48 & 23,3 \\
\hline & $11-15$ tahun & 7 & 3,4 \\
\hline & 16-20 tahun & 5 & 2,4 \\
\hline & $>20$ tahun & 2 & 1,0 \\
\hline
\end{tabular}


Berdasarkan Tabel 1 di atas, responden penelitian berjenis kelamin laki-laki adalah 84,5 persen presentase tersebut lebih banyak daripada responden berjenis kelamin perempuan yaitu 15,5 persen. Mayoritas usia responden adalah 2630 tahun (28,2 persen), mayoritas tingkat pendidikan terakhir responden adalah SMA (49,5 persen), responden penelitian mayoritas sudah menikah (66,5 persen) namun mayoritas responden tidak/belum memiliki anak (45,1 persen), selain itu lama bekerja responden mayoritas adalah 1-5 tahun (54,9 persen).

\section{Uji Outliers}

Dalam penelitian ini, jumlah variabel independen yang digunakan adalah 2 (dua) konstruk -konflik keluarga-pekerjaan dan motivasi intrinsik, maka nilai degree of freedom dapat dihitung, $d f=2-1-1$ pada tabel $t$ dengan $p<$ 0,001 adalah 318,31. Apabila hasil perhitungan squared mahalanobis distance > 318,31 maka data tersebut diidentifikasi sebagai outliers. Hasil uji outliers terdapat pada Tabel 2 yang terdiri atas 5 (lima) data terbesar dan 5 (lima) data terkecil nilai squared mahalanobis distance, dengan bantuan program SPSS 16.0 for Windows.

Tabel 2. Hasil Uji Outliers - Squared Mahalanobis Distance

\begin{tabular}{ccc}
\hline Data & $\begin{array}{c}\text { Nilai Squared } \\
\text { Mahalanobis } \\
\text { Distance }\end{array}$ & $\begin{array}{c}\text { Nilai Squared } \\
\text { Mahalanobis Distance } \\
\text { yang Diharapkan }\end{array}$ \\
\hline 141 & 14.78 & \\
197 & 11.01 & \\
45 & 10.11 & \\
196 & 7.87 & Squared \\
92 & 7.67 & Mahalanobis \\
. &. & Distance \\
. &. & $<318,31$ \\
. &. & \\
177 & 0.090 & \\
72 & 0.003 & \\
128 & 0.003 & \\
134 & 0.003 & \\
199 & 0.003 & \\
\hline
\end{tabular}

Sumber: Hasil pengolahan data

Berdasarkan hasil pengujian squared mahalanobis distance pada Tabel 2 di atas, tidak terdapat data/kasus outliers. Dengan demikian, sebanyak 206 data akan digunakan pada analisisanalisis selanjutnya.

\section{Uji Validitas}

Uji validitas konstruk dilakukan dengan menggunakan analisis faktor konfirmator atau confirmatory factor analysis (CFA). Sunjoyo (2005) mengatakan bahwa secara umum, nilai analisis faktor untuk setiap dimensi atau konstruk dinyatakan valid dan dapat diterima adalah dengan nilai absolut factor loading $\geq 0,4$ (rule of thumbs). Tiga konstruk penelitian terdiri dari 18 (delapan belas) butir pernyataan. Konflik keluarga-pekerjaan, motivasi intrinsik, dan kinerja kerja secara berturut-turut terdiri atas 7 (tujuh), 4 (empat), dan 7 (tujuh) butir. Ketika analisis faktor dilakukan untuk menguji validitas konstruk, 18 (delapan belas) butir pernyataan dinyatakan bervaliditas baik. Hasil perhitungan uji validitas dapat dilihat pada Tabel 3 dengan bantuan program SPSS 16.0 for Windows.

Tabel 3. Factor Loadings Setiap Butir dan

Konstruk dengan Analisis Faktor

\begin{tabular}{ccccc}
\hline Konstruk* & Butir* & $\begin{array}{c}\text { Komponen/ } \\
\text { Faktor }\end{array}$ & $\begin{array}{c}\text { Komponen/ } \\
\text { Faktor }\end{array}$ & $\begin{array}{c}\text { Komponen/ } \\
\text { Faktor }\end{array}$ \\
\hline \multirow{6}{*}{ KKP } & KKP1 &, 538 & & \\
& KKP2 &, 624 & & \\
& KKP3 &, 523 & & \\
& KKP4 &, 628 & & \\
& KKP5 &, 685 & & \\
& KKP6 &, 676 & & \\
& KKP7 &, 470 & & \\
\hline \multirow{6}{*}{ MI } & MI1 & &, 851 & \\
& MI2 & &, 838 & \\
& MI3 & &, 758 & \\
& MI4 & &, 671 &, 743 \\
& KK1 & & &, 829 \\
& KK2 & & &, 809 \\
& KK3 & & &, 728 \\
KK & KK4 & & &, 677 \\
& KK5 & & &, 662 \\
& KK6 & & &, 670 \\
\hline
\end{tabular}

Sumber: Hasil pengolahan data

*KKP= Konflik Keluarga-pekerjaan, MI= Motivasi Intrinsik, KK= Kinerja Kerja

\section{Uji Reliabilitas}

Uji reliabilitas dilakukan dengan menggunakan Cronbach's alpha. Hasil pengujian reliabilitas menunjukkan bahwa 18 (delapan belas) butir instrument riset memenuhi kriteria Cronbach's alpha. Sekaran (seperti yang dikutip dalam Rantika \& Sunjoyo, 2011) menyatakan bahwa koefisien Cronbach's alpha yang kurang dari 0,6 adalah buruk, antara 0,6 dan 0,8 dapat diterima, dan di atas 0,8 adalah baik.' Hasil perhitungan 
uji reliabilitas dapat dilihat pada Tabel 4 dengan bantuan program SPSS 16.0 for Windows.

Tabel 4. Koefisien Cronbach's Alpha Konstruk-konstruk Riset

\begin{tabular}{cc}
\hline Konstruk* $^{*}$ & Koefisien Cronbach's Alpha \\
\hline KKP &, 737 \\
MI &, 836 \\
KK &, 884 \\
\hline
\end{tabular}

Sumber: Hasil pengolahan data

*KKP $=$ Konflik Keluarga-pekerjaan, MI= Motivasi Intrinsik, KK= Kinerja Kerja

\section{Uji Statistik Deskriptif dan Korelasi Antarkonstruk Penelitian}

Pengujian korelasional antarkonstruk bertujuan untuk mengetahui seberapa kuat dan apakah signifikan hubungan antarkonstruk penelitian menurut Sunjoyo (seperti yang dikutip dalam Putri, 2016). Hasil perhitungan uji statistik deskriptif dan korelasi antarkonstruk penelitian dapat dilihat pada Tabel 5.

Tabel 5. Hasil Uji Statistik Deskriptif dan Korelasional Antarkonstruk

\begin{tabular}{clllllllllll}
\hline No. & Var & $\boldsymbol{M}$ & \multicolumn{1}{c}{$\boldsymbol{S D}$} & $\mathbf{1}$ & $\mathbf{2}$ & $\mathbf{3}$ & $\mathbf{4}$ & $\mathbf{5}$ & $\mathbf{6}$ & $\mathbf{7}$ & $\mathbf{8}$ \\
\hline $\mathbf{1}$ & JK & 1,16 &, 36 & & & & & & & & \\
$\mathbf{2}$ & $\mathbf{U S}$ & 2,7 & 1,30 &,- 055 & & & & & & & \\
$\mathbf{3}$ & PD & 2,86 &, 99 &, 182 &, 091 & & & & & & \\
$\mathbf{4}$ & SP & 1,67 &, 47 &,- 008 &, 558 &,- 038 & & & & & \\
$\mathbf{5}$ & JA & 1,96 & 1,03 &, 005 &, $625^{* *}$ &,$- 158^{*}$ &, $649^{* *}$ & & & & \\
$\mathbf{6}$ & LB & 2,26 &, 91 &, 024 &, $479^{* *}$ &,- 115 &, $363^{* *}$ &, $417^{* *}$ & & & \\
$\mathbf{7}$ & KKP & 3,87 &, 49 &, 071 &,- 108 &, 027 &,- 014 &,- 065 &,- 069 & & \\
$\mathbf{8}$ & MII & 4,28 &, 55 &, 132 &, 108 &, $297^{* *}$ &, 086 &,- 013 &,- 014 &, $361^{* *}$ & \\
$\mathbf{9}$ & KK & 3,63 &, 01 &, 097 &, 045 &, $213^{* *}$ &, $168^{*}$ &, 032 &,- 034 &, $496^{* * *}$ &, $444^{* *}$ \\
\hline
\end{tabular}

Sumber: Hasil pengolahan data.

$* * p<0,01 ; * p<0,05$.

$M=$ mean $; S D=$ standar deviasi; $\mathrm{JK}=$ jenis kelamin; US = Usia; $\mathrm{PD}=$ pendidikan; $\mathrm{SP}=$ status perkawinan; $\mathrm{JA}=$ jumlah anak; $\mathrm{LB}=$ lama bekerja; $\mathrm{KKP}=$ konflik keluarga-pekerjaan; $\mathrm{MI}=$ motivasi intrinsik; $\mathrm{KK}=$ kinerja kerja.

Hasil analisis pada Tabel 5 maka dapat disimpulkan bahwa nilai mean dan standar deviasi pada konflik keluarga-pekerjaan $(M=$ $3,87 ; S D=0,49)$ dan kinerja kerja $(M=3,63 ; S D$ $=0,61)$ hasil perhitungan tersebut menunjukkan tingkat mean yang relatif tinggi. Sementara pada konstruk motivasi intrinsik, menunjukkan tingkat mean dan standar deviasi yang relatif sangat tinggi $(M=4,28 ; S D=0,55)$. Selanjutnya, Tabel 5 menunjukkan bahwa terdapat korelasi secara positif antara pendidikan dan motivasi intrinsik $(r=0,297 ; p<0,01)$ dan kinerja kerja $(r=0,213$; $p<0,01)$ tetapi keduanya tergolong rendah. Vionita (2013) menyatakan dalam meningkatkan kinerja pegawai dan untuk memotivasi pegawai dalam bekerja adalah melalui pendidikan.

Tabel 5 menunjukkan variabel kontrol lain yang memiliki pengaruh terhadap kinerja kerja adalah status pernikahan, menunjukkan korelasi secara positif $(r=0,168 ; p<0,05)$ namun tergolong sangat rendah. Purbadi dan Sofiana (seperti yang dikutip dalam Kumajas, Warouw, \& Bawotong, 2014) yang menyatakan bahwa individual yang telah menikah akan meningkat dalam kinerja karena mempunyai pemikiran yang lebih matang dan bijaksana yang sangat diperlukan dalam penerapan prinsip etik. Peneliti menduga bahwa hasil temuan riset ini $(r=0,361$; $p<0,01)$ disebabkan karena terdapat 66,5 persen responden yang menyatakan telah menikah dan pernikahan akan mendorong rasa tanggung jawab sebagai salah satu bentuk motivasi intrinsik karyawan tersebut.

Tabel 5 menunjukkan bahwa terdapat korelasi secara positif antara konflik keluargapekerjaan dan kinerja kerja $(r=0,496 ; p<0,01)$. Artinya, konflik keluarga-pekerjaan dan kinerja kerja memiliki korelasi yang cukup berarti. Hasil penelitian ini bertentangan dengan hasil penelitian yang dilakukan oleh Tjokro dan Asthenu (2010) dan Indriyani (2009) yang menunjukkan bahwa terdapat pengaruh negatif konflik keluarga-pekerjaan terhadap kinerja kerja. Namun mendukung hasil penelitian yang dilakukan oleh Talitha dan Santosa (2012) yang menyatakan bahwa terdapat hubungan positif searah antara konflik keluarga-pekerjaan dan kinerja kerja karyawan. Selain itu Tabel 5 menunjukkan bahwa terdapat korelasi secara positif antara motivasi intrinsik dan kinerja kerja $(r=0,444 ; p<0,001)$ artinya motivasi intrinsik memiliki korelasi yang cukup berarti. Wilson (seperti yang dikutip dalam Suparta, 2013) menyatakan bahwa motivasi intrinsik sangat memengaruhi seseorang dalam mengembangkan kompetensinya yang berujung pada peningkatan kinerjanya.

\section{Uji Goodness of Fit Model}

Sebelum melakukan uji hipotesis dilakukan terlebih dahulu uji Analysis of Variance (ANOVA) atau $F$ test untuk pengajuan fit model antara teoritis dan data empiris. Dikatakan "good fit" apabila $p<0,05$. sementara "poor fit" apabila $p>0,05$ menurut Sunjoyo (seperti yang dikutip dalam Inkiriwang, 2013). Hasil uji 
ANOVA dapat dilihat pada Tabel 5 dengan bantuan program SPSS 16.0 for Windows.

Tabel 6. Hasil Uji ANOVA

\begin{tabular}{llccccc}
\hline \multirow{2}{*}{ Model } & $\begin{array}{c}\text { Sum of } \\
\text { Squares }\end{array}$ & df & $\begin{array}{c}\text { Mean } \\
\text { Squares }\end{array}$ & F & Sig \\
\hline \multirow{4}{*}{1} & Regression & 24,71 & 2 & 12,35 & & \\
& Residual & 50,92 & 203 &, 251 & 49,26 &, 000 \\
& Total & 75,63 & 205 & & & \\
\hline
\end{tabular}

Sumber: Hasil pengolahan data.

a. Predictors: (Constant), KKP, MI

b. Dependent Variabel: KK

Tabel 6 di atas menunjukkan bahwa nilai $F$ adalah 49,26 dengan probabilitas 0,000 ( $p<$ 0,01 ). Secara statistik signifikan pada tingkat $p<$ 0,05 , sehingga dapat disimpulkan bahwa model penelitian "good fit". Dengan demikian, konflik keluarga-pekerjaan dan motivasi intrinsik dapat digunakan sebagai prediktor kinerja kerja secara empiris.

\section{Uji Hipotesis}

Uji hipotesis dilakukan dengan analisis regresi linier majemuk dengan tingkat signifikansi $p<$ 0,05 . Sugiyono (2007) menyatakan analisis regresi linier majemuk digunakan untuk meramalkan bagaimana keadaan (naik turunnya) variabel dependen, bila dua atau lebih variabel independen sebagai faktor prediktor (dinaikturunkan nilainya). Hipotesis ini bertujuan untuk menguji apakah konflik keluarga-pekerjaan $(K K P)$ memengaruhi secara negatif kinerja kerja $(K K)$ dan motivasi intrinsik $(M I)$ memengaruhi secara positif kinerja kerja. Hasil uji hipotesis dapat dilihat pada Tabel 7 dengan bantuan SPSS 16.0 for Windows.

Tabel 7. Hasil Pengujian

Hipotesis 1 dan Hipotesis 2

\begin{tabular}{lllllll}
\hline \multirow{2}{*}{ Model } & \multicolumn{3}{c}{ Unstandardized } & \multirow{2}{*}{$\boldsymbol{t}$} & \multirow{2}{*}{ Sig } & Hasil \\
\cline { 2 - 5 } & & $\boldsymbol{\beta}$ & Std. & & & \\
\hline & Constant &, 324 &, 336 &, 966 &, 335 & \\
Hipotesis 1 & $\mathrm{KKP}$ &, 482 &, 077 & 6,253 &, 000 & Tidak didukung \\
Hipotesis 2 & $\mathrm{MI}$ &, 336 &, 119 & 4,930 &, 000 & Didukung \\
\hline
\end{tabular}

Sumber: Hasil pengolahan data.

\section{Pengujian Hipotesis 1}

Hipotesis 1 tidak didukung. Hasil yang diperoleh berdasarkan uji hipotesis, menunjukkan bahwa konflik keluarga-pekerjaan justru memberikan pengaruh positif terhadap kinerja kerja sebesar
48,2 persen $(\beta=0,482 ; p<0,01)$. Namun demikian, hasil riset ini didukung oleh hasil penelitian yang dilakukan oleh Christine, Oktorina, dan Mula (2010) serta Widyaningrum, Pongtuluran, dan Tricahyadinata (2013) yang menyatakan konflik keluarga-pekerjaan memiliki pengaruh positif terhadap kinerja kerja.

\section{Pengujian Hipotesis 2}

Hipotesis 2 didukung $(\beta=0,336 ; p<0,01)$. Hasil pengujian hipotesis ini mengkonfirmasi berbagai hasil penelitian terdahulu (Astrini, 2012; Lukito dkk., 2013; Suparta, 2013; Karatepe \& Tekinkus, 2006; Maulana dkk., 2015; serta Sleimi \& Davut, 2015) yang menyatakan bahwa motivasi intrinsik berpengaruh positif terhadap kinerja kerja.

\section{IMPLIKASI MANAJERIAL}

Hasil riset menunjukkan bahwa konflik keluargapekerjaan berpengaruh positif terhadap kinerja kerja (48,2 persen) dan motivasi intrinsik berpengaruh positif terhadap kinerja kerja $(33,6$ persen). Tabel 5 menunjukkan tingkat konflik keluarga-pekerjaan pada 3 perusahaan, tergolong tinggi $(M=3,87 ; S D=0,49)$. Namun kondisi tersebut justru memberikan pengaruh positif terhadap kinerja kerja para karyawan. Hal ini diduga terjadi karena sebesar 66,5 persen responden telah menikah dan diduga adanya beberapa karyawan yang memiliki suami/istri yang sama-sama bekerja. Mereka mampu memahami pekerjaan masing-masing sehingga konflik pekerjaan-keluarga yang terjadi dapat dikelola untuk meningkatkan kinerja (Christine dkk., 2010). Upaya yang dapat dilakukan oleh manajemen perusahaan dalam mengatasi tingginya tingkat work-family conflict di antaranya adalah dengan mendorong karyawan untuk membina hubungan pribadi dengan para sahabat (rekan kerja), mendorong karyawan untuk memperhatikan kesehatan dan mental, menurut Burke dkk. (seperti yang dikutip dalam Karatepe \& Tekinkus, 2006). Salah satunya adalah melalui acara gathering atau outbond. Selain untuk mendorong hubungan dengan rekan kerja, kegiatan di acara gathering atau outbond akan mendorong keaktifan dari diri karyawan baik secara mental maupun fisik.

Tabel 5 menunjukkan tingkat motivasi intrinsik karyawan pada 3 perusahaan tergolong sangat tinggi $(M=4,28 ; S D=0,55)$ serta memengaruhi kinerja kerja secara positif sebesar 33,6 persen dan hasil riset ini dapat dikategorikan baik. Motivasi intrinsik berkaitan 
dengan motivasi yang berasal dari dalam diri seseorang misalnya, keinginan untuk berprestasi, tanggung jawab pada sebuah pekerjaan dan keinginan untuk mengembangkan diri. Untuk mendorong motivasi intrinsik karyawan, diperlukan usaha dari pihak manajemen perusahaan. Krisdiyanto (2010) menyatakan pihak manajemen perusahaan dapat memotivasi karyawan melalui program-program seperti program insentif yang tepat, teknik membangun sebuah tim, pertemuan-pertemuan dengan staf, seminar dan workshop. Selain itu, Muafi (2009) menyatakan manajemen perusahaan perlu memberikan kesempatan kepada para karyawan untuk mengembangkan diri misalnya dengan cara meningkatkan partisipasi karyawan dalam hal pengambilan keputusan. Selanjutnya, perusahaan dapat memberikan reward (penghargaan) kepada setiap karyawan yang telah memenuhi tanggung jawabnya dengan baik. Mardansyah dan Sari (2013) menyatakan sistem penghargaan dirancang agar mampu memotivasi dan meningkatkan kinerja kerja para karyawan.

\section{SIMPULAN}

Tujuan penelitian ini adalah untuk menguji dan menganalisis apakah konflik keluarga-pekerjaan berpengaruh negatif terhadap kinerja kerja dan apakah motivasi intrinsik berpengaruh positif terhadap kinerja kerja. Selain itu, untuk menguji seberapa tinggi tingkat konflik keluargapekerjaan, motivasi intrinsik dan kinerja kerja serta seberapa kuat korelasi antara konflik keluarga-pekerjaan dan motivasi intrinsik, konflik keluarga-pekerjaan dan kinerja kerja serta motivasi intrinsik dan kinerja kerja. Berdasarkan hasil penelitian yang telah dilakukan, maka dapat disimpulkan bahwa konflik keluarga-pekerjaan berpengaruh positif terhadap kinerja kerja sebesar 48,2 persen. Dengan demikian Hipotesis 1 tidak didukung. Selain itu, hasil riset menunjukkan bahwa motivasi intrinsik berpengaruh positif terhadap kinerja kerja sebesar 33,6 persen sehingga Hipotesis 2 didukung. Selanjutnya pada hasil penelitian menunjukkan tingkat mean dan standar deviasi konflik keluarga-pekerjaan $(M=$ $3,87 ; S D=0,49)$, motivasi intrinsik $(M=4,28$; $S D=0,55)$, dan kinerja kerja $(M=3,63 ; S D=$ 0,61 ) yang menunjukkan tingkat relatif tinggi untuk konstruk konflik keluarga-pekerjaan dan kinerja kerja serta tingkat relatif sangat tinggi untuk konstruk motivasi intrinsik.

\section{Keterbatasan Penelitian dan Saran bagi Penelitian Mendatang}

Dalam melakukan penelitian, peneliti menghadapi beberapa keterbatasan. Pertama, peneliti hanya menggunakan kuesioner untuk pengambilan data. Kedua, peneliti hanya mengambil sampel pada perusahaan yang bergerak di bidang jasa dan manufaktur.

Adapun beberapa saran yang hendak peneliti sampaikan bagi penelitian mendatang, antara lain:

1. Penelitian mendatang diharapkan tidak hanya menggunakan kuesioner sebagai teknik pengumpulan data tetapi dapat melakukan wawancara dan observasi.

2. Menambahkan beberapa anteseden dan konsekuensi lain untuk tiap konstruk penelitian. Anteseden konflik keluargapekerjaan yaitu work overload (Elloy \& Smith, 2004), role conflict, role ambiguity (Elloy \& Smith, 2004), locus of control (Noor, 2006). Konstruk yang dapat menjadi outcomes dari konflik kerja-keluarga yaitu turnover intention (Agustina, 2008), turnover, motivasi, dan absenteeism (Triaryati, 2003), organizational citizhen behavior (Balmforth \& Gardner, 2006), serta keterlibatan kerja (Panggabean, 2006).

3. Pengambilan sampel bisa diperluas ke beberapa perusahaan yang bergerak di bidang jasa dan manufaktur, seperti bidang makanan dan minuman, konstruksi, dan lainnya, sehingga hasil studi untuk setiap industri dapat diperbandingkan.

\section{Saran bagi Perusahaan}

1.Pihak manajemen perusahaan perlu melakukan upaya untuk mendorong karyawan untuk membina hubungan pribadi dengan para sahabat (rekan kerja), mendorong karyawan untuk memperhatikan kesehatan fisik dan mental, menurut Burke et al. (seperti yang dikutip dalam Karatepe \& Tekinkus, 2006).

2.Dalam meningkatkan motivasi intrinsik karyawan, manajemen perusahaan perlu memberikan kesempatan bagi karyawan untuk mengembangkan kemampuan pribadinya. Misalnya, dengan melibatkan karyawan dalam pengambilan keputusan atau melalui program-program seperti program insentif yang tepat, teknik membangun sebuah tim, pertemuanpertemuan dengan staf, seminar dan workshop. 
3.Pemberian reward (penghargaan) sebagai motivasi ekstrinsik dapat menjadi salah satu acara untuk mempertahankan karyawan untuk mendemonstrasikan kinerja yang baik. Penghargaan dapat diberikan melalui kenaikan gaji, pemberian bonus, pemberian wewenang, promosi, dan pemberian sertifikat dan plakat.

\section{REFERENSI}

Agustina, L. (2008). Pengaruh work-family conflict terhadap job satisfaction dan turnover intention pada profesi akuntan publik: Studi empiris pada kantor akuntan publik di DKI Jakarta dan Bandung. Jurnal Ilmiah Akuntansi, 7(2), 100-116.

Arfiansyah, A. (2014). Pengaruh kompensasi dan konflik kerja terhadap kinerja karyawan (Studi pada Kantor PT Pos Indonesia (Persero) Mail Processing Center Semarang). Tugas akhir, Universitas Diponegoro, Semarang, Indonesia. Diperoleh dari http://eprints.undip.ac.id/44608/1/10_AF RIANSYAH.pdf

Astikariandini, P. M. (2009). Analisis ekuitas merek shampoo sunsilk. Tugas akhir, Universitas Indonesia, Depok, Indonesia). Diperoleh dari http://lib.ui.ac.id/file?file=digital/123132 -6671-Analisis\%20ekuitasMetodologi.pdf

Astrini, R. (2012). Pengaruh motivasi intrinsik dan motivasi ekstrinsik terhadap produktivitas kerja pegawai pada Kantor Pelayanan Kekayaan Negara dan Lelang Makasar. Tugas akhir, Universitas Hasanuddin, Makasar, Indonesia. Diperoleh dari https://core.ac.uk/download/pdf/2548696 1.pdf

Babin, B. J. \& Boles, J. S. (1998). Employee behavior in service environment: a model and test of potential differences between men and women. Journal of Marketing (62), 77-91

Balmforth, K. \& Gardner, D. (2006). Conflict and facilitation between work and family: Realizing the outcomes for organizations. New Zealand Journal of Psychology, 35(2), 69-76

Elloy, D. F. \& Smith, C. (2004). Antesedents of work-family conflict among dual-career couples: An Australian study. Cross Cultural Management, 11 (4), 17-27.

Etikan, I., Musa, S. A., \& Alkassim, R. S. (2015). Comparison of convenience sampling and purposive sampling. American Journal of Theoretical and Applied Statistics, 5(1), 1-4. Diperoleh dari

http://article.sciencepublishinggroup.co m/pdf/10.11648.j.ajtas.20160501.11.pdf

Greenhaus, J. H. \& Beutell, N. J. (1985). Sources of conflict between work and family roles. Academv of Management Review, 10(1), 76-88. Diperoleh dari http://www.jstor.org/stable/258214

Hakim, B. A. (2016). Pengaruh budaya organisasi, komitmen dan kompensasi terhadap kinerja karyawan: Studi di PT Madu Baru Yogyakarta. Tesis magister, Universitas Muhammadiyah Yogyakarta, Yogyakarta, Indonesia. Diperoleh dari http://pascasarjana.umy.ac.id/wpcontent/uploads/2016/10/96-BaktiAmrinul-Hakim.pdf

Harshanty, A. W. (2011). Pengaruh motivasi terhadap kinerja karyawan Badan Perijinan Terpadu (BPT) Kabupaten Sragen. Tesis magister, Univeristas Sebelas Maret, Surakarta, Indonesia. Diperoleh dari https://eprints.uns.ac.id/10246/1/189470 811201103551.pdf

Inkiriwang, F. M. (2013). Pengaruh big five personality terhadap kepuasan kerja karyawan operasional [Database: TA]. Tugas akhir, Universitas Kristen Maranatha, Bandung, Indonesia.

Istomo, S. W. (2013). Pengaruh manajemen konflik terhadap kinerja karyawan pada PT Taspen (Persero) Kantor Cabang Yogyakarta. Tugas akhir, Universitas Negeri Yogyakarta, Yogyakarta, Indonesia). Diperoleh dari http://eprints.uny.ac.id/17108/1/TUGAS $\% 20$ AKHIR.pdf

Kusumawardhani T. D., Suprayitno, \& Utami S. S. (2014). Pengaruh konflik peran, konflik keluarga-pekerjaan dan pekerjaan berlebih terhadap kinerja karyawan PT Air Mancur di Wonogiri. Jurnal Ekonomi dan Kewirausahaan, 14(2), 230-241. Diperoleh dari http://ejurnal.unisri.ac.id/index.php/Ekon omi/article/view/882/734 
Linawati. (2014). Pengaruh motivasi kerja intrinsik dan motivasi kerja ekstrinsik terhadap kinerja karyawan: Studi pada PT Angkasa Pura I Bandar Udara Internasional Ahmad Yani Semarang. Kinerja, 8(1), 81-89. Diperoleh dari https://ojs.uajy.ac.id/index.php/kinerja/ar ticle/download/519/569

Lukito, H. P., Haryono, A. T., \& Warso, M. M. (2016). Pengaruh motivasi intrinsic motivasi ekstrinsik dan pengalaman kerja terhadap kinerja karyawan: Studi pada BTPN Syariah Semarang). Journal of Management, 2(2), 1-16. Diperoleh dari

http://jurnal.unpand.ac.id/index.php/MS/ article/view/603/587

Karatepe, O. M. \& Tekinkus, M. (2006). The effects of work-family conflict, emotional exhaustion and intrinsic motivation on job outcomes of front-line employees. International Journal of Bank Marketing, 24(3), 173-193. Diperoleh dari

http://dx.doi.org/10.1108/026523206106 59021

Kumajas, F., Warouw, H., \& Bawotong, J. (2014). Hubungan karakteristik individu dengan kinerja perawat di ruang rawat inap penyakit dalam RSUD Datoe Binangkang Kabupaten Bolaang Mongondow. Jurnal Keperawatan, 2(2), 1-8. Diperoleh dari https://ejournal.unsrat.ac.id/index.php/jk p/article/viewFile/5304/4817

Maulana, F. H., Hamid, D., \& Mayoan, Y. (2015). Pengaruh motivasi ekstrinsik, motivasi intrinsik dan komitmen organisasional terhadap kinerja karyawan pada Bank BTN Kantor Cabang Malang. Jurnal Administrasi Bisnis, 22(1), 1-8. Diperoleh dari http://download.portalgaruda.org/article. php? article $=326551 \&$ val $=6468 \&$ title $=\mathrm{P}$ ENGARUH\%20MOTIVASI\%20INTRI NSIK,\%20MOTIVASI\%20EKSTRINSI K\%20DAN\%20KOMITMEN\%20ORG ANSASI\%20TERHADAP\%20KINERJ A\%20KARYAWAN\%20PADA\%20BA NK\%20BTN\%20KANTOR\%20CABA NG\%20MALANG.

Muafi. (2009). Riset tentang peran partisipasi dalam pengambilan keputusan dan dukungan kelompok yang dipersepsikan dalam menciptakan keinginan untuk bekerjasama, IV (2), 199-208. Diperoleh dari

repository.upnyk.ac.id/1769/1/Partisipasi _dlm_PK.pdf

Mudayana, A. A. (2010). Pengaruh motivasi dan beban kerja terhadap kinerja karyawan di Rumah Sakit Nur Hidayah Bantul. Jurnal Kesehatan Masyarakat, 4(2), 76143.

Diperolehdari https://www.google.co.id/url?sa=t\&rct=j $\& \mathrm{q}=\&$ esrc $=\mathrm{s} \&$ source $=$ web $\& c d=15 \&$ ved $=0$ ahUKEwiaJmkxb3TAhVJLMAKHfT 9CIc4ChAWCEEwBA\&url=http $\% 3 \mathrm{~A} \%$ 2F\%2Fwww.journal.uad.ac.id\%2Findex. php\%2FKesMas\%2Farticle\%2Fdownloa d\%2F1098\%2Fpdf_17\&usg=AFQjCNE VrT6Abkeb23sMFBLqFow48TDYIQ\&s ig2=v6tA4TC1 miCv70smQ8415A

Muizzudin, A. (2014). Hubungan knowledge sharing dengan kinerja karyawan di PT Citra Utama Niaga Nusantara. Tesis magister, Universitas Islam Negeri Sunan Ampel, Surabaya, Indonesia). Diperoleh dari http://digilib.uinsby.ac.id/249/

Mulyandini, A. D., Lelly, S. W., \& Tobing, D.S. (2015). Self efficacy sebagai mediasi pengaruh work family conflict dan iklim kerja terhadap kinerja karyawati perbankan: Studi pada dual career couple di Bank BRI dan Bank BTN Cabang Jember). Artikel Ilmiah Mahasiswa. Diperoleh dari http://repository.unej.ac.id/bitstream/han dle/123456789/64298/ALFEONITA\%20 DYAH\%20MULYANDINI.pdf?sequenc $\mathrm{e}=1$

Noor, M. N. (2006). Locus of control, supportive workplace policies and work-family conflict. Pyschologia, (49), 48-60.

Panggabean, M. S. (2006). Hubungan diantara keterlibatan kerja, kepuasan kerja, dan komitmen organisasi. Jurnal Manajemen Sumber Daya Manusia dan Organisasi 1(1), 1-34

Prahiawan, W. \& Simbolon, N. (2014). Pengaruh motivasi intrinsik dan lingkungan kerja terhadap kinerja karyawan pada PT Intimas Lestari Nusantara. Jurnal Ekonomi, 5(1), 35-41. Diperoleh dari http://download.portalgaruda.org/article. php?article $=314599 \&$ val $=4567 \&$ title $=\mathrm{Pe}$ ngaruh Motivasi Intrinsik dan Lingkungan Kerja Terhadap Kinerja 
Karyawan Pada PT Intimas Lestari Nusantara.

Rantika, R. \& Sunjoyo. (2011). Pengaruh konflik kerja-keluarga terhadap komitmen organisasional yang dimediasi oleh kepuasan kerja pada profesi perawat di Rumah Sakit Umum Daerah (RSUD) Dr. Moewardi Surakarta. Jurnal Manajemen Teori dan Terapan, 4(2), 28-43. Diperoleh dari e journal.unair.ac.id/index.php/JMTT/artic le/viewFile/2418/177

Roboth, J. Y. (2015). Analisis work-family conflict, stres kerja dan kinerja wanita berperan ganda pada Yayasan Compassion East Indonesia. Jurnal Riset Bisnis dan Manajemen, 3(1),33-46. Diperoleh dari http://ejournal.unsrat.ac.id/index.php/jrb $\mathrm{m} /$ article/view/7517/7061

Sekaran, U. \& Bougie, R. (2009). Research methods for business: A skill building approach $\left(5^{\text {th }}\right.$ Ed.). UK, West Sussex: John Wiley \& Sons Ltd.

Siregar, D. Y. (2011). Gambaran work family conflict pada perawat wanita di Rumah Sakit Umum Padangsidimpuan. Tugas akhir, Universitas Sumatera Utara, Medan, Indonesia. Diperoleh dari http://repository.usu.ac.id/handle/123456 $789 / 26690$

Sugiyono. (2012). Metode Penelitian Bisnis. Bandung: Alfabeta

Sleimi, M. T. \& Davus, S. (2015). Intrinsic and extrinsic motivation: Povital role in bank tellers satisfaction and performance: Case study of Palestinian Local Banks. International Journal of Business and Social Science, 6(11), 127-136. Diperoleh dari http://www.ijbssnet.com/journals/Vol_6 _No_11_November_2015/16.pdf

Suparta, A. G. (2013). Pengaruh motivasi intrinsik, komunikasi, dan kompensasi finansial terhadap kinerja karyawan pada PT Maharani Preman Sakti Denpasar. Universitas Udayana. Bali, Indonesia. 2(5), 530-540. Diperoleh dari http://download.portalgaruda.org/article. php? article $=82447 \&$ val $=989$

Sunjoyo. (2005). Pengaruh persepsi keadilan organisasional terhadap komitmen organisasional afektif para dosen: Sebuah studi pada Fakultas Ekonomi Universitas Kristen Maranatha Bandung.
Laporan riset yang tidak dipublikasikan, Universitas Kristen Maranatha, Bandung.

Sutanto, V. \& Mogi, J. A. (2016). Pengaruh work-family conflict terhadap stres kerja dan kinerja karyawan di Restoran The Duck King Imperial Chef Galaxy Mall Surabaya. Jurnal Hospitality dan Manajemen Jasa, 4(1), 377-391. Diperoleh dari http://studentjournal.petra.ac.id/index.ph $\mathrm{p} /$ manajemen-perhotelan/article/view/41 $63 / 0$

Tjokro, C. I. \& Asthenu, J. R. (2015) Pengaruh konflik peran ganda dan stress kerja terhadap kinerja perawat Rumah Sakit Umum Dr. H. Maulussy Ambon.

Triaryati, N. (2003). Pengaruh adaptasi kebijakan mengenai work family issue terhadap absen dan turnover. Jurnal Manajemen dan Kewirausahaan, 5(1), 85-96.

Utami, S. B. (2013). Pengaruh kualitas layanan dan kinerja karyawan terhadap kepuasan nasabah pada PT Taspen (Persero) Cabang Yogyakarta. Tesis magister, Universitas Negeri Yogyakarta, Yogyakarta, Indonesia. Diperoleh dari http://eprints.uny.ac.id/16370/1/TUGAS \%20AKHIR\%20-\%2010409131012.pdf

Vionita, V. (2013). Pengaruh tingkat pendidikan dan motivasi kerja terhadap kinerja pegawai tata usaha SMK Negeri di Kota Payakumbuh. Tugas akhir, Universitas Negeri Padang, Padang, Indonesia. Diperoleh dari http://ejournal.unp.ac.id/students/index.p hp/pek/article/viewFile/444/245

Yavas, U., Babakus, E., \& Karatepe, O. (2008). Attitudinal and behavioral consequences of work-family conflict and family-work conflict. International Journal of Service Industry Management, 19(1), 7-31. Diperoleh dari www.emeraldsight.com/0956-4233.htm 
Jurnal Manajemen Maranatha 匹 Vol. 18 Nomor 1, November (2018) 